\title{
Uji Performa Kompor Induksi dan Kompor Gas Terhadap Pemakaian Energi dan Aspek Ekonomisnya
}

\author{
Septianissa Azzahra ${ }^{1}$; Hastuti Azis ${ }^{2}$; Meyhart Torsna Bangkit Sitorus ${ }^{3}$; Pawenary $^{4}$ \\ 1, 2,3,4 Institut Teknologi PLN \\ ${ }^{1}$ septianissa@itpln.ac.id
}

\begin{abstract}
Stove is a tool that people used to provide foods to meet the basic of human needs. By far every social class in every society used a gas stove to fill up this needs simply because its easy-to-get and its cheap price reasoning (Indonesian government still subsidize their $3 \mathrm{~kg}$ cooking gas tank that makes its prices very affordable). Today, however, Indonesian government persuade people to use induction stoves as a replacement of gas stoves to reduce an increasing number of Indonesian's gas importing. In previous study, a comparison between gas, electric and induction stove was conducted by testing that all stove on boiling 1 litre of water. In this study, we conducted a performance test of a gas stove and an induction cooker in its daily use (for 4 weeks) by comparing their energy consumptions and the economical aspects. The results of this research stated that the induction stove is more efficient since it only used $9900.571 \mathrm{~kJ}$ in 4 weeks compared with a gas stove which used $225389.75 \mathrm{~kJ}$ in the same time period at the same workloads. However, from economical aspect, induction cooker cost greater than the subsidized gas stove at Rp. 4048.45,- in compared to Rp. 2400,-, whilst the nonsubsidized gas stove costs Rp. 5625,-.at the same workloads.
\end{abstract}

Keywords: Performance Test, Induction Stove, Gas Stove, Energy Consumption, Cost

\begin{abstract}
ABSTRAK
Kompor merupakan kebutuhan sehari-hari yang digunakan masyarakat sebagai alat untuk menyediakan berbagai makanan guna memenuhi kebutuhan pokok. Penggunaan kompor gas sangat umum digunakan oleh berbagai kalangan karena mudah didapat dan ekonomis (Pemerintah di Indonesia masih mensubsidi tabung gas $3 \mathrm{~kg}$ sehingga harganya sangat terjangkau). Namun saat ini pemerintah mendorong masyarakat untuk menggunakan kompor induksi sebagai pengganti dari kompor gas untuk mengurangi impor gas yang selama ini jumlahnya terus meningkat. Pada penelitian sebelumnya dilakukan perbandingan antara penggunaan kompor gas, listrik, dan induksi dengan mengujinya dalam mendidihkan 1 liter air. Pada penelitian ini dilakukan pengujian performa kompor gas dan kompor induksi dalam penggunaannya sehari-hari dengan membandingkan pemakaian energi dan aspek ekonomisnya selama 4 minggu. Dari hasil penelitian yang telah dilakukan menyatakan bahwa pemakaian energi pada kompor induksi dalam 4 miinggu lebih hemat energi dengan pemakaian sebesar 9900,571 kJ dibandingkan dengan kompor gas yaitu 225389,75 kJ di periode waktu yang sama. Namun dari keekonomian, kompor induksi menghabiskan biaya lebih besar yaitu Rp. 4048,45,- dibandingkan dengan kompor gas yang menggunakan gas subsidi yaitu sebesar Rp. 2400,-. Sedangkan untuk biaya pemakaian kompor gas dengan gas nonsubsidi besarnya biaya adalah Rp. 5625,-.
\end{abstract}

Kata Kunci: Uji Performa, Kompor Induksi, Kompor Gas, Pemakaian Energi, Biaya 


\section{Energi dan Kelistrikan: Jurnal Ilmiah}

Vol. 12, No. 2, Juli - Desember 2020, P-ISSN 1979-0783, E-ISSN 2655-5042

https://doi.org/10.33322/energi.v12i2.1009

\section{PENDAHULUAN}

Kompor merupakan kebutuhan sehari-hari yang digunakan masyarakat sebagai alat untuk menyediakan berbagai makanan guna memenuhi kebutuhan pokok. Penggunaan kompor gas sangat umum digunakan oleh berbagai kalangan karena mudah dibeli dan dari segi biaya sangat terjangkau karena adanya subsidi dari pemerintah yang menyebabkan harga gas sangat terjangkau.

Pemerintah kini mendorong penggunaan kompor induksi agar masyarakat mulai beralih dari penggunaan kompor gas ke kompor induksi. Inovasi kompor induksi dinilai dapat mengurangi impor gas yang selama ini dilakukan untuk memenuhi kebutuhan konsumsi Liquid Petroleum Gas (LPG) 3 kilogram.

Upaya pemerintah dalam mentransformasi penggunaan kompor gas menjadi kompor induksi ini bertujuan untuk menghemat biaya yang cukup signifikan karena biaya penggunaan kompor induksi diperkirakaan hanya 50-60\% dari penggunaan kompor gas.

Oleh karena hal tersebut diatas, perlu adanya penelitian lebih lanjut terhadap performa dari kompor gas dan kompor induksi agar pada pemakaiannya di masyarakat dapat dibandingkan dari segi penggunaan energi dan aspek ekonomisnya sehingga masyarakat dapat mengetahui perbedaan dan keuntungan dari pemakaian kompor-kompor tersebut.

Penelitian ini akan dilakukan untuk menguji performa beberapa jenis kompor induksi dan kompor gas seperti besarnya pemakaian energi dan biaya yang diperlukan dalam penggunaannya.

\section{METODE/PERANCANGAN PENELITIAN}

\subsection{Tahapan Penelitian}

Tahapan penelitian yang akan dilakukan pada penelitian ini adalah sebagai berikut :

a. Pengambilan data pengukuran kompor induksi meliputi tegangan, arus listrik, perubahan waktu dan faktor daya untuk mengetahui besarnya energi listrik yang digunakan selama pemakaian kompor induksi.

b. Pengambilan data pengukuran kompor gas meliputi massa gas (sebelum dan sesudah digunakan) untuk mengetahui besarnya jumlah kalor yang digunakan dan data perubahan waktu.

c. Pengolahan data hasil pengukuran berupa perhitungan.

d. Studi hasil pengukuran dan perhitungan pemakaian energi dan biaya dari penggunaan kompor induksi dan kompor gas

e. Penarikan kesimpulan dari hasil pengukuran dan perhitungan pemakaian energi dan biaya dari penggunaan kompor induksi dan kompor gas

\subsection{Persamaan yang digunakan dalam penelitian}

\subsubsection{Energi Listrik}

Usaha atau energi listrik dapat pula dinyatakan dalam persamaan sebagai berikut:

$$
\mathbf{W}=\text { V.I.t }
$$

Dimana :

$$
\begin{aligned}
& \mathrm{I}=\text { Kuat arus listrik (ampere) } \\
& \mathrm{V}=\text { Beda potensial (volt) } \\
& \mathrm{t}=\text { waktu (sekon) } \\
& \mathrm{W}=\text { Usaha atau Energi listrik (Watt.sekon atau Joule) }
\end{aligned}
$$

\subsubsection{Energi Panas (Kalor)}


Apabila suatu zat atau benda mengalami perubahan bentuk atau wujud pada suhu yang tetap, maka diperlukan sejumlah kalor dalam proses tersebut. Besarnya jumlah kalor yang diperlukan tersebut dapat dinyatakan dalam persamaan berikut ini :

$\mathbf{Q}=\mathbf{m} \cdot \mathbf{L}$

Dimana :

$\mathrm{Q}=$ Jumlah kalor yang dilepaskan atau diserap (Joule)

$\mathrm{m}=$ Massa benda atau zat $(\mathrm{kg})$

$\mathrm{L}=$ Banyaknya kalor yang dilepaskan/diserap setiap perubahan bentuk atau wujud suatu zat per satuan massa atau dapat disebut juga sebagai Heating Value (Joule/Kg)

\subsection{Spesifikasi peralatan yang digunakan pada penelitian}

2.3.1. Spesifikasi Peralatan pada Pengujian Kompor Induksi

Jenis/Merk Kompor Induksi

Daya Maksimum Kompor

Induksi

Daya Listrik Rumah Tangga

Tarif Dasar Listrik Rumah

Tangga $1300 \mathrm{VA}$

Daya maksimum yang digunakan
: Kompor Induksi 2 Tungku

: Tungku 1 (Maks.1600 W) \& Tungku 2

(Maks.1300 W)

: $1300 \mathrm{VA}$

: Rp. 1467,28 / kWh

: 1000 watt (daya listrik rumah adalah 1300 VA dengan mempertimbangkan penggunaan peralatan listrik yang lainnya)

2.3.2. Spesifikasi Peralatan pada Pengujian Kompor Gas

Jenis/Merk Kompor Gas

Massa Tabung Gas Sebelum digunakan

Kandungan/Komposisi Gas

Harga gas LPG $3 \mathrm{~kg}$
: Kompor Gas 2 Tungku

$: 5,5 \mathrm{Kg}$

: 30\% Propana dan $70 \%$ Butana

: Rp. 16.000

\section{HASIL DAN PEMBAHASAN}

\subsection{Pengujian Kompor Induksi}

Pengujian pada kompor induksi dilakukan sebanyak 4 kali pengukuran. Pengukuran dilakukan 1 kali tiap minggunya dengan parameter pengukuran seperti yang akan dijelaskan pada tabel 1 dibawah ini.

Tabel 1. Data Pengujian Kompor Induksi dengan daya 1000 watt

\begin{tabular}{|c|c|c|c|c|c|}
\hline $\begin{array}{c}\text { Pengukuran } \\
\text { ke- }\end{array}$ & Tegangan (V) & Arus (A) & Cos $\boldsymbol{\varphi}$ & $\begin{array}{c}\text { Waktu } \\
\text { pemakaian } \\
\text { (menit) }\end{array}$ & $\begin{array}{c}\text { Daya } \\
\text { (watt) }\end{array}$ \\
\hline 1 & 220 & 3,97 & 0,90 & 7 & 786,06 \\
\hline 2 & 221 & 3,94 & 0,90 & 5 & 783,67 \\
\hline 3 & 221 & 3,95 & 0,90 & 8 & 785,66 \\
\hline 4 & 221 & 3,96 & 0,90 & 10 & 787,64 \\
\hline $\begin{array}{c}\text { Rata-rata } \\
\text { perhari }\end{array}$ & $\mathbf{2 2 0 , 7 5}$ & $\mathbf{3 , 9 5 5}$ & $\mathbf{0 , 9 0}$ & $\mathbf{7 , 5}$ & $\mathbf{7 8 5 , 7 6}$ \\
\hline
\end{tabular}

3.1.1. Waktu yang digunakan pada pemakaian kompor induksi selama 4 minggu adalah sebagai berikut :

$\mathrm{t}=$ waktu pemakaian rata-rata per hari (menit) $\mathrm{x} 28$ hari 


\section{Energi dan Kelistrikan: Jurnal Ilmiah}

Vol. 12, No. 2, Juli - Desember 2020, P-ISSN 1979-0783, E-ISSN $2655-5042$

https://doi.org/10.33322/energi.v12i2.1009

$$
\begin{aligned}
& =7,5 \text { menit } \mathrm{x} 28 \text { hari } \\
& =210 \text { menit } \\
& =3,5 \mathrm{jam}
\end{aligned}
$$

3.1.2. Besarnya pemakaian energi listrik pada penggunaan kompor induksi 1000 watt selama 4 minggu adalah sebagai berikut :

$$
\begin{aligned}
\mathrm{W} & =\mathrm{V} . \mathrm{I} \cdot \cos \varphi . \mathrm{t} \\
& =220,75 \times 3,955 \times 0,90 \times 3,5 \\
& =2750,159 \mathrm{watt} \mathrm{jam} \\
& =2,750159 \mathrm{kWh} \\
& =9900,571 \mathrm{kWs} \text { atau } 9900,571 \mathrm{~kJ}
\end{aligned}
$$

3.1.3. Besarnya pemakaian biaya listrik pada penggunaan kompor induksi 1000 watt selama 4 minggu adalah sebagai berikut :

$$
\begin{aligned}
\text { Biaya } & =\text { Energi listrik terpakai } x \text { Tarif Listrik }(\mathrm{Rp} . / \mathrm{kWh}) \\
& =2,759159 \mathrm{kWh} \times \mathrm{Rp} .1467,28 / \mathrm{kWh} \\
& =\mathrm{Rp} .4048,45
\end{aligned}
$$

\subsection{Pengujian Kompor Gas}

Pada pengujian kompor gas ini dilakukan pengukuran sebanyak 4 kali yang dilakukan dengan mengukur massa tabung gas dan waktu rata-rata pemakaian kompor selama 4 minggu. Pengukuran dilakukan 1 kali setiap 7 hari. Data hasil pengukuran pada pengujian kompor gas dapat dilihat pada table 2 berikut ini.

Tabel 2. Data Pengujian Kompor Gas

\begin{tabular}{|c|c|c|c|}
\hline $\begin{array}{c}\text { Pengukuran } \\
\text { Ke- }\end{array}$ & Hari ke- & $\begin{array}{c}\text { Massa Tabung Gas LPG } \\
(\text { Kg) }\end{array}$ & $\begin{array}{c}\text { Waktu } \\
\text { pemakaian rata- } \\
\text { rata per hari } \\
\text { (menit) }\end{array}$ \\
\hline 1 & 1 & 5,5 & - \\
\hline 2 & 7 & 5,35 & 10 \\
\hline 3 & 14 & 5,15 & 15 \\
\hline 4 & 21 & 5,05 & 5 \\
\hline
\end{tabular}

3.2.1. Massa gas yang terpakai selama pemakaian 4 minggu

Massa gas terpakai= Massa tabung gas sebelum pemakaian - massa tabung gas setelah pemakaian 4 minggu

$$
\begin{aligned}
& =5,5 \mathrm{~kg}-5,05 \mathrm{~kg} \\
& =0,45 \mathrm{~kg}
\end{aligned}
$$

3.2.2. Besarnya pemakaian energi panas (kalor) yang digunakan pada pemakaian kompor gas selama 4 minggu.

Komposisi gas LPG terdiri dari 30\% Propana dan 70\% Butana, sehingga massa yang terpakai dari senyawa-senyawa tersebut adalah

Massa Propana $=30 \% \mathrm{x}$ massa gas terpakai

$$
\begin{aligned}
& =30 \% \times 0,45 \mathrm{~kg} \\
& =0,135 \mathrm{~kg}
\end{aligned}
$$

Besarnya energi panas (kalor) yang digunakan adalah sebagai berikut : 
$\mathrm{Q}=\mathrm{m} . \mathrm{L}$

Dimana untuk senyawa Propana memiliki Heating Value (L) sebesar 50,35 MJ/kg atau sama dengan $50350 \mathrm{~kJ} / \mathrm{kg}$

Sehingga Q Propana $\quad=0,135 \mathrm{~kg} \times 50350 \mathrm{~kJ} / \mathrm{kg}$

$=6797,25 \mathrm{~kJ}$

Massa Butana $\quad=70 \% \times$ massa gas terpakai

$=70 \% \times 0,45 \mathrm{~kg}$

$=0,315 \mathrm{~kg}$

Besarnya energi panas (kalor) yang digunakan adalah sebagai berikut :

$\mathrm{Q}=\mathrm{m} . \mathrm{L}$

Dimana untuk senyawa Butana memiliki Heating Value (L) sebesar 49,5 MJ/kg atau sama dengan $49500 \mathrm{~kJ} / \mathrm{kg}$

Sehingga Q Butana $\quad=0,315 \mathrm{~kg}$ x $49500 \mathrm{~kJ} / \mathrm{kg}$

$=15592,5 \mathrm{~kJ}$

Total energi panas yang digunakan pada penggunaan kompor gas selama 4 minggu adalah :

$$
\begin{aligned}
\mathrm{Q} \text { total } & =\mathrm{Q} \text { propane }+\mathrm{Q} \text { butana } \\
& =6797,25 \mathrm{~kJ}+15592,5 \mathrm{~kJ} \\
& =225389,75 \mathrm{~kJ}
\end{aligned}
$$

3.2.3. Besarnya pemakaian biaya pada penggunaan kompor gas selama 4 minggu adalah :

Harga gas LPG 3 kg (subsidi) $=$ Rp. $16000 / 3 \mathrm{~kg}$

$$
=\mathrm{Rp} .5333,33 / 1 \mathrm{~kg}
$$

Massa gas yang terpakai $=0,45 \mathrm{~kg}$

Biaya pemakaian kompor gas selama 4 minggu $=\mathrm{Rp} .5333,33 \times 0,45 \mathrm{~kg}$

$$
=\text { Rp. } 2400
$$

$$
\begin{aligned}
\text { Harga gas LPG } 12 \mathrm{~kg} \text { (non subsidi) } & =\mathrm{Rp} .150 .000 / 12 \mathrm{~kg} \\
& =\mathrm{Rp} .12 .500 / 1 \mathrm{~kg}
\end{aligned}
$$

Massa gas yang terpakai $=0,45 \mathrm{~kg}$

Biaya pemakaian kompor gas selama 4 minggu $=\mathrm{Rp} .12 .500 \times 0,45 \mathrm{~kg}$

$$
=\text { Rp. } 5625
$$

\subsection{Perbandingan Hasil Penggunaan Energi dan Biaya pada Kompor Induksi dan Kompor Gas}

Hasil perbandingan dari perhitungan pemakaian energi dan biaya pada kompor induksi dan kompor gas selama pemakaian 4 minggu ditunjukkan pada table berikut ini: 


\section{Energi dan Kelistrikan: Jurnal Ilmiah}

Vol. 12, No. 2, Juli - Desember 2020, P-ISSN 1979-0783, E-ISSN 2655-5042

https://doi.org/10.33322/energi.v12i2.1009

Tabel 3. Data hasil perbandingan pemakaian energi dan biaya pada kompor induksi dan kompor gas selama 4 minggu pemakaian.

\begin{tabular}{|c|c|c|c|}
\hline Jenis & Pemakaian Energi & $\begin{array}{c}\text { Pemakaian Biaya } \\
\text { (Tarif Subsidi) }\end{array}$ & $\begin{array}{c}\text { Pemakaian Biaya (Tarif } \\
\text { Non Subsidi) }\end{array}$ \\
\hline $\begin{array}{c}\text { Kompor Induksi } \\
\text { (1000 watt) }\end{array}$ & $9900,571 \mathrm{~kJ}$ & - & Rp. 4048,45,- \\
\hline Kompor Gas & $225389,75 \mathrm{~kJ}$ & Rp. 2400,- & RP. 5625,- \\
\hline
\end{tabular}

\section{KESIMPULAN DAN SARAN}

Berdasarkan penelitian yang telah dilakukan selama 4 minggu, maka dapat disimpulkan bahwa pemakaian energi pada kompor induksi lebih sedikit (lebih hemat energi) yaitu sebesar 9900,571 kJ dibandingkan dengan kompor gas dengan pemakaian energi sebesar 225389,75 kJ. Namun dari segi pemakaian biaya pada kompor induksi masih lebih tinggi yaitu sebesar Rp.4048,45,- dibandingkan dengan kompor gas yaitu Rp.3150,- . Hal ini disebabkan karena harga gas LPG 3 kg masih disubsidi oleh pemerintah sehingga pemakaian biaya oleh penggunaan kompor gas lebih ekonomis dibandingkan dengan penggunaan kompor induksi. Sedangkan jika dibandingkan dengan pemakaian kompor gas $12 \mathrm{~kg}$ non subsidi yang pemakaian biayanya adalah sebesar Rp. 5625,- maka penggunaan kompor induksi lebih ekonomis dari pada penggunaan kompor gas.

\section{UCAPAN TERIMA KASIH}

Dalam penyusunan dan pelaksanaan penelitian ini saya ingin mengucapkan terima kasih kepada institusi dimana saya mengabdi yaitu Institut Teknologi PLN yang mendukung terlaksananya kegiatan penelitian ini. Tak lupa juga saya menyampaikan terima kasih kepada mahasiswamahasiswa yang terlibat dalam membantu pengambilan data serta kepada pihak Laboratorium Bengkel D3 Teknologi listrik yang membantu dalam menyediakan sarana dan prasarana guna menunjang kegiatan penelitian ini.

\section{DAFTAR PUSTAKA}

[1] Adipura, B. (2016). Induksi Elektromagnetik. Kementrian Pendidikan Dan Kebudayaan RI, 1-7. https://doi.org/10.1039/b309115e

[2] AFROX. Product Reference Manual - Section 5 - Liquefied Petroleum Gas

[3] Asas Black. (n.d.). Retrieved from https://id.wikipedia.org/wiki/Asas_Black

[4] Emeralds, R. O. N. (1873). Kemagnetan.

[5] Hasanah, Aas Wasri, dkk. 2016. Perbandingan efisiensi energi dan biaya pada kompor induksi terhadap kompor listrik dan kompor gas.

[6] Induksi Elektromagnetik. $\quad$ (n.d.). $\quad$ Retrieved from https://id.wikipedia.org/wiki/Induksi_elektromagnetik

[7] NIST Chemistry webbook. webbook.nist.gov

[8] Peraturan Menteri Energi dan Sumber Daya Mineral Nomor 3 Tahun 2020 tentang Perubahan Keempat Atas Peraturan Menteri Energi dan Sumber Daya Mineral Nomor 28 Tahun 2016 tentang Tarif Tenaga Listrik Yang Disediakan Oleh PT Perusahaan Listrik Negara (Persero)

[9] Peraturan Menteri Keuangan Nomor 116/PMK.02/2016 tentang Tata Cara Penyediaan Anggaran, Penghitungan, Pembayaran, dan Pertanggungjawaban Dana Subsidi Liquefied Petroleum Gas (LPG) Tabung 3 Kilogram 
[10] Satriawan, M. (2012). Fisika Dasar (Vol. 8). https://doi.org/10.14710/teknik.v29i3.2177

[11] Syahbardia. (2011). Pengujian Prestasi Kompor Induksi. Seminar Nasional Teknik Mesin 7.

[12] Syukur, M. Hasan. 2011. Penggunaan Liquified Petroleum Gases (LPG) : Upaya Mengurangi Kecelakaan Akibat LPG. Jurnal Forum Teknologi Vol.1 No.2. PPSDM Migas.

[13] Te, L., \& Negeri, S. (n.d.). Fisika a ( Tkf F 202 ).

[14] Toft, Lasse. 2016. International Experinces With LPG Subsidy Reform. International Institute for Sustainable Development. https://www.iisd.org/sites/default/files/publications/international-experiences-with-LPGsubsidy-reform.pdf

[15] Well-to-Wheel Studies, Heating Values, and The Energy Conservation Principle. European Fuel Cell Forum. October 2003. 